\title{
The Applying of Hypothetical Learning Trajectory (HLT) on Comparison Material Using Nisab Zakat Theory toward The Student's Learning outcomes
}

\author{
Yudi Yunika Putra ${ }^{1}$, Adi Saputra ${ }^{2}$ \\ 1,2 STKIP Muhammadiyah Bangka Belitung \\ Correspondence Address; yudi.yunikaputra@stkipmbb.ac.id
}

\begin{abstract}
The problems in learning mathematics, especially comparative material, have not combined with religious theory in the learning process. The merging of Knowledge , especially mathematics with the knowledge of religion is very important, because in addition to getting mathematics, the student will directly learn about the knowledge of religion. The comparative learning using the Nisab Zakat theory will encourage to bring out reasoning abilities and students think creatively, and innovative in solving the problem. The aims of the research is to find out how the influence of applying of HLT toward the student's reasoning on the third semester of Education of elementary teacher department in STKIP Muhammadiyah Bangka Belitung. The research method of this research is quasi-experimental design. Data collection techniques are tests with hypothesis testing using t-test statistical formula. The average value of pretest before HLT applied in learning is 64.7 with a minimum value of 49 , and a maximum value of 75.8 . While the value on the post-test after being applied to HLT obtained an average value of 86.4 with the minimum value of 67 and the maximum value of 100 . Then with this it can be concluded that there is a positive effect of the application of HLT (Hypothetical Learning Trajectory) comparison material using the Nisab zakat theory on results Student learning mathematics comparison material.
\end{abstract}

Keywords: Mathmatics, Nisab Zakat, Reasoning , Comparison.

\section{INTRODUCTION}

The Comparison is one of the basic Knowledge for learning mathematics, science, and is useful in the real world as well as various life situations (Utari, Putri, \& Hartono, 2015). The Questions in daily life make it easier for students to use literacy skills and answer questions, can challenge mathematical thinking patterns (Putra, Zulkardi, \& Hartono, 2016). So it is very good if the mathematics learning material is combined with the daily problems. (Sumarto, Galen, Zulkardi, \& Darmawijoyo, 2013) The Students are still having difficulty in solving comparison problem questions, especially in solving the problem of comparing reversals, The student difficulties in finding patterns of questions and explaining reasons using the method in solving questions while comparison material is always included about the Final National Examination (Sholohin, \& Paris, 2017; Febrian, Hartoyo, \& Suratman, 2016).

The Comparative material can be interpreted with the concept of religion which is closely related to the daily and the zakat theory, the combining of the knowledge of religion in mathematics learning is very important, between them there are points that complement and strengthen, even Islam becomes the source of knowledge (Hidayatulloh, 2016). Understanding of Islamic values needs to be instilled in students (Salafudin: 2015). It is expected that students can identify comparative problems of value and understand the ratio in comparison of values. Whereas in the theory of zakat fitrah a person is obliged to pay zakat fitrah for 2.5 kilograms 
of rice, so that both concepts can be combined into learning. In learning, students are required to always be involved in the learning process, so that it will provide a stimulus to students that learning the material is very important. Students will better understand the concept of comparison if they are involved in learning activities (Safaredha, 2014). This involvement is in accordance with the concept of the Hypotetical Learning Trajectory (HLT) where the learning path is designed in oder to the student can be directly involved in the learning process. Hypothetical Learning Trajectory (HLT) is the learning flow consisting of learning objectives, learning activities, and learning process hypotheses to predict how students' thoughts and understanding will develop in the context of learning activities (Simon, 1995, Mendrofa, 2017)

Based on previous research, several studies have been carried out in the use of the Hypothetical Learning Trajectory (HLT) method (Ayunika et al., 2011; Charitas, Prahmana, \& Kusumah, 2016; Elizondo \& Hernández-solís, 2016; Fuadiah, 2017; Ilma \& Putri, 2012; Johar, 2016; Megawati, Siahaan , \& Andriani, 2014; Nurdin, 2011; Ramadhanti, 2015; Risnanosanti, 2012; Septiono \& Darminto, 2014; Wijaya, 2015) and several mathematical researches that discussed the comparison material (Agustina \& Amin, 2013; Argarini, Budiyono, \& Sujadi, 2014; Fitriana, Yusuf, \& Susanti, 2016; Misrianti, Sugiatno, \& Hamdani, 2014; Pertiwi, 2017; Rahayu, Retno, \& Saputro, 2015; Rudiono, Dafik, \& Wahyuningrum, 2015; Susilo \& Khabibah, 2013; Trianingsih \& Hidayah, 2014; Utari, 2017; Wibowo, Rif'at, \& Hamdani, 2015) and the charitable organization of zakat have been reduced in several previous researches (Asnaini, 2015; Hadi., 2016; Jamhur, 2014; Munif, 2012; Nuruddin, 2014; Ridwan, 2014; Yusefri, 2017) and also measurements of the result of previous researches (Asmawati \& Wuryanto, 2014; Hasanah, 2016; Kristin \& Rahayu, 2016; Kusmaryono, 2015; Maulidiyahwarti, Sumarmi, \& Amirudin, 2016; Pratiwi \& Santosa, 2013; Rhamandica, Wonorahardjo, \& Arief, 2016). However, no prior research has been applied to apply the Hypothetical Learning Trajectory (HLT) method to the comparison materials that use the theory of Nisab Zakat on the results of learning. Thus, this research objective is to find out the effect of the Hypothetical Learning Trajectory (HLT) method on the comparison material using the Nisab Zakat theory on learning outcomes.

\section{THE RESEARCH METHODS}

The type of research used was quasi-experimental design with the design of the one group pretest-post test design where in a group or class research was given treatment, but before the treatment, the student was given the pretest after that the treatment and also was given the posttest . The learning process with the application of the Hypothetical Learning Trajectory (HLT) in the comparison material using the Nisab Zakat theory, and the final results analyzed are in the form of numbers, and hypothesis testing using statistical formulas.

In this research there are 2 (two) variables, namely the independent variable or variable is "The application of the Hypothetical Learning Trajectory (HLT) in the comparison material using the Nisab Zakat theory. While the dependent variable (dependent variable) or the variable $\mathrm{y}$ in this research is "learning outcomes".The design can be described as follows. 
Table 1. Experimental Research Design

\begin{tabular}{ccc}
\hline Class & Treatment & Final test \\
\hline Experimental Class 1 & $X_{1}$ & $O_{1}$ \\
Experimental Class 2 & $X_{2}$ & $O_{2}$ \\
\hline
\end{tabular}

Description:

$X_{1} \quad=$ Contextual treatment

$X_{2} \quad=$ Treatment using the HLT approach

$O_{1}=O_{2}=$ Final test (posttest) experimental class 1 and experimental class 2

Before hypothesis testing is done, the analysis prerequisite test is done first on the students' initial abilities, for the balance test with a 0.05 level of significance. Test the analysis prerequisites of the normality test using the Lillifors test, the homogeneity test. If the test results are normally distributed and come from the same area of variance, then the Statistical Hypothesis is tested using the t-test.

Assumptions for normality tests, namely:

$H_{0}$ : Data is normally distributed

$H_{1}$ : Data is not normally distributed

Test Criteria: if $L_{\text {count }}<L_{\text {table }}$ then $H_{0}$ s accepted, so that both data are normally distributed. Assumption for homoginity test, Namely:

$H_{0}$ : Homogenity Data

$H_{1}$ : Data is not Homogen.

Test Criteria: if $F_{\text {count }}<F_{\text {table }}$ then $H_{0}$ accepted, so that both data are homogeneous. Comparison of hypotheses is carried out based on the right party test hypothesis formula. If $T_{\text {count }} \leq T_{\text {table }}$, then $H_{O}$ accepted. The hypotheses tested are:

$H_{O}: \mu_{1} \leq \mu_{2}$

$H_{1}: \mu_{1}>\mu_{2}$

$\mu_{1}$ : Learning outcomes with the contextual method

$\mu_{2}$ : Learning outcomes with HLT Method

The sampling technique uses cluster random sampling technique and hypothesis testing using the t-test. (Sugiyono, 2016).

$$
t_{\text {tes }}=\frac{\bar{X}_{1}-\bar{X}_{2}}{\sqrt{\frac{s_{1}^{2}}{n_{1}}+\frac{s_{2}^{2}}{n_{2}}}-2 r\left(\frac{s_{1}}{\sqrt{n_{1}}}\right)\left(\frac{s_{2}}{\sqrt{n_{1}}}\right)}
$$

\section{THE RESULTS OF THE RESEARCH AND THE DISCUSSION}

This research is a quasi-experimental design. The design used in this study is the one group pretest - post test design. In this reserch before applying the Hypothetical Learning Trajectory (HLT) on comparison material using the Nisab Zakat theory was given at the pretest and after applaying The HLT Method, the posttest was performed to see whether there were 
differences in learning outcomes before applaying HLT and after applying HLT. If there are differences in the value of the pretest and the post test value, it can be said that there is the influence of the Hypothetical Learning Trajectory (HLT) comparison material using the Nisab Zakat theory on student learning outcomes.

The pretest is done before doing learning / treatment which aims to measure the extent the students understand the comparison material and the concept of Nisab Zakat. In thisresearch using the Hypothetical Learning Trajectory (HLT) in the comparison material using the Nisab Zakat theory. The question is the pretest as shown in Figure 1 below.

\section{Banyaknya zakat fitrah yang telah dikeluarkan oleh 3 keluarga, yaitu keluarga \\ A, keluarga B, dan keluarga C sebanyak 45 'kg. Rasio jumlah anggota ketiga \\ keluarga tersebut berturut-urut $2: 3: 4$ : Tentukan banyaknya anggota keluarga \\ masing-masing keluarga? Jelaskan alasanmu!}

Figure 1. Pretest Question

In answering the problem of some students who are not correct in answering questions. From the observations it was found that most of them have not mastered the concept of comparison, and there are still many who do not know the magnitude of the zakat fitrah. However, most students in working on the pretest problem found that they have used comparison theory to solve problems. Likewise with the answers to the students' pretest in figure 2 below, The students appropriate in determining many members of each family, which corresponds to the problems in the problem. Figure 2 below is the student's answer sheet.

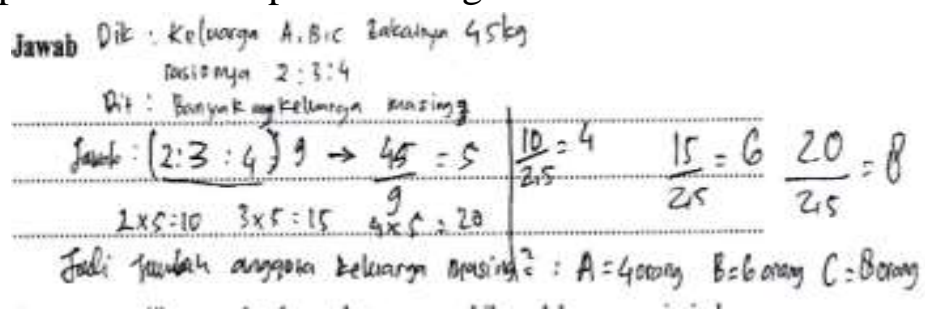

Figure 2. Pretest Answer .

After the pretest, the application of the Hypothetical Learning Trajectory (HLT) was carried out on the comparison material using the Nisab Zakat theory. To design a learning activity, it is necessary to know the picture of student thinking that can participate in learning activities and be able to consider and anticipate student reactions. HLT consists of three main components, namely 1) learning objectives for the student; 2) learning activities and devices / media used in the learning process; and 3) the conjecture of the learning process how to know students' understanding and strategies that arise and develop when learning activities are done in the classroom (Gravemeijer, 2004).

Each Student Activity Sheet (LAM) arranged has determined the learning objectives to be achieved, from the purpose is designed a sheet of learning activities, where each activity requires students to think critically in solving the problem. the results of activities the conjecture or the student's answer is expected in solving the problem. 
In the application the researcher divides the research subject into four groups, and allows each group to sit with their respective groups to discuss LAM given. Figure 3 below is LAM Stage

1. Dalam satu keluatga terdapat 6 (enam) anggota keluarga yang terdiri dari Ayah, Ibu, dan 4 orang anak, yang terdiri 2 laki-laki dar1 2 perempuan. Dalam hukum zakat fitraht bahtwa selunh orang wajh mengeluarkan zakat fitrah. Maka

1. keluarga tersebul menueluarkan akat fitrah sobexar? jelaskan alasarimu.
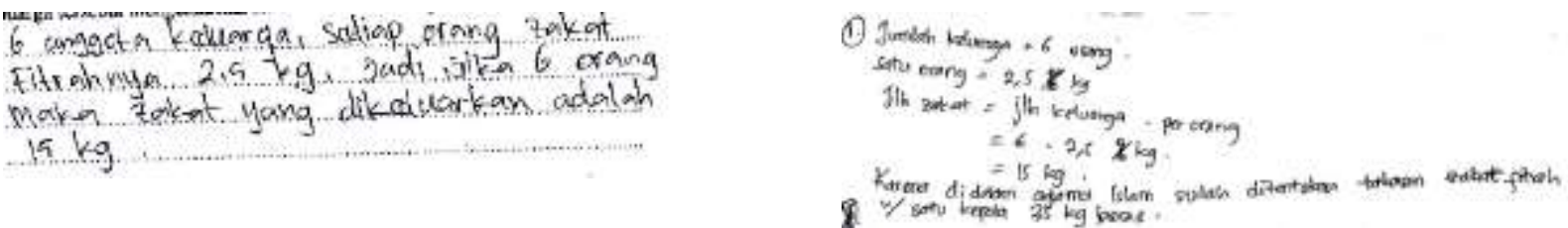

Figure 3. LAM meeting 1 and Group 1 and Group 2

Answers Transcript of group conversations in working on LAM 1 is as follows.

A : How about number 1?

$B$ : number 1, the member of family each member pays Zakat fitarh 2,5 kg. So if 6 member must pay zakat fitrah $15 \mathrm{~kg}$

A : Ooh

$B$ : yes, 6 times $2,5 \mathrm{~kg}$

A : why must pay $2,5 \mathrm{~kg}$

$B$ : because the rule of zakat fitrah must pay $2,5 \mathrm{~kg}$

$A$ :How about the questions table, could I get the information.

B : yes, you could,here many family pay zakat fitrah for 10 people $25 \mathrm{~kg}$.so every person must pay $2,5 \mathrm{~kg}$

$A$ : can I see there?

$B$ : yes $m r$.

$A$ :if we don't now the rule must be $2,5 \mathrm{~kg}$, by lok the information on the table, can I answer it?

$B$ : yes, you can, because the amount

A :Ooh, I see?

$B$ :yes sir.

Descripton:
A : lecturer
B : Group 1

Based on the transcript of the conversation above, it can be seen that students have understood the amount of zakat fitrah that must be issued by each person. In addition, in determining the amount of zakat fitrah can be seen in the information about the question by comparing the amount of zakat fitrah 10 people is $25 \mathrm{~kg}$, then each person $2.5 \mathrm{~kg}$.

In the stage 1 of LAM, the students are able to identify comparative value problems using the amount of zakat fitrah and zakat mal Nisab, and students are able to understand the ratio in 
the comparison of values. On the issue of LAM 1 using the theory of the amount of zakat alms of fitrah, and some magnitude of the zakat syariah law.

The question requires students to be able to determine the amount of zakat that must be released in a family of 6 people. The findings obtained in answering question number 1, the two groups were correct in determining the final results, but did not use the concept of comparison in answering the questions.

The two groups above answer the questions with two different answers. In the first group they immediately determined the amount of zakat fitrah for each person $2.5 \mathrm{~kg}$ compared to 6 people, then the amount of zakat fitrah must be spent is $15 \mathrm{~kg}$. While group 2 answered the question by determining the number of families compared to the amount of zakat fitrah each person.

The next discussion is about the results in stage 2. LAM in stage 2 as seen in figure 4 below.

(1.) Dalam satu keluarga terdapat 6 (enam) anggota keluarga yang terdiri dari Ayah, Ibu, dan 4 orang anak, yang terdin 2 laki-laki dan 2 perempuan. Dalam hukum zakat fitrah bahwa seluruh orang wajib mengeluarkan zakat fitrah. Maka keluarga tersebut mengetuarkan zakat fitrah sebesar? jelaskan alasanmu!

Figure 4. LAM stage 2

The total of 4 groups discussed completing the LAM that had been given. The results of the analysis of the learning process and student answers found that they were very enthusiastic in discussing, and they were able to solve the problem correctly. As Figure 5 below is the answer of students in stage 2 .
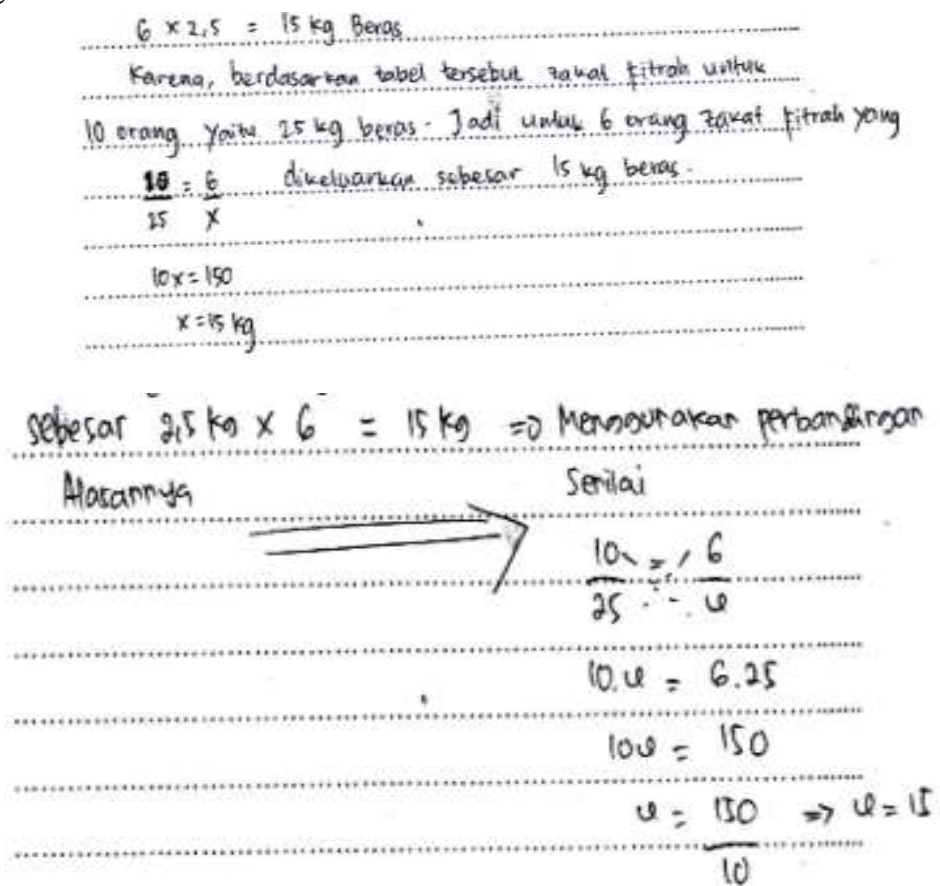

Figure 5 The answer sheet stage 2 
In the answer to Figure 5 above, it was found that all groups answered the questions correctly. They are able to communicate the question's problems in making conclusions and are able to use the concept of comparison in solving problems. From the results of observations during the learning process it was found that all students had understood the magnitude of zakat fitrah that must be issued by each individual. So they easily use their reasoning abilities to solve problems.

After the implementation of the Hypothetical Learning Trajectory (HLT) was completed, all research subjects were given a final test (post-test) which was done individually. In the final test phase it aims to see the extended of students understand the concept of comparison both in solving the problem of missing value and the problem of comparison as well as the extended of students are internal to solve the problem.

Furthermore, the price of $t_{\text {count }}$ is compared with $t_{\text {table }}$ with the following criteria.

$\mathrm{t}$ Count $>\mathrm{t}$ tabel so $H_{a}$ is accepted then $H_{o}$ is rejected

$\mathrm{t}$ Count $\leq \mathrm{t}$ tabel so $H_{a}$ is accepted then $H_{o}$ is rejected

The calculation results as in table 1 below.

Table 1. Hypothesis Test Results

\begin{tabular}{cc}
\hline $\mathrm{T}_{\text {count }}$ & $\mathrm{t}_{\text {tabel }}$ \\
\hline 3,218 & 2,045 \\
\hline
\end{tabular}

Based on the calculation results, it is found that $\mathrm{t}_{\text {count }}$ is 3,218 and $\mathrm{t}_{\text {tabel }}$ is 2,045 . because $3,218>2,045$ so $H_{a}$ is accepted $H_{o}$ is rejected. This means that there is a positive influence on the application of the Hypothetical Learning Trajectory (HLT) on the comparison material using the Nisab Zakat theory on student learning outcomes.

The use of zakat Nisab theory is used as the starting point in Comparison material learning. In addition, the use of the zakat theory adds scientific evidence that the knowledge of religion and knowledge cannot be separated, the two sciences can go hand in hand or together. In addition, in completing the activity sheet, the student is very enthusiastic and motivated in discussing problems.

Freudenthal (in Gravemeijer \& Van Eerde, 2009) holds that students are given the opportunity to develop and develop their ideas and thoughts when constructing the mathematics. Lecturers can choose appropriate learning activities as the basic for stimulating students to think and act when constructing the mathematics (Prahmana: 2017).

In this research, the researcher made the learning design of Hypothetical Learning Trajectory (HLT), in the comparison material using the Nisab Zakat theory. Graveimeijer \& Cobb (2006) state that HLT is the hypothesis (guess) from situational problems that are contextual to formal mathematics in the learning process.

The various researches using HLT's Hypothetical Learning Trajectory have been conducted. Ayunika uses the Hypothetical Learning Trajectory (HLT) for improving student's understanding of the concepts. From the results of her research it can be concluded that with the help of the Hypothetical Learning Trajectory (HLT) can build students' understanding of mathematical concepts, the use of the Hypothetical Learning Trajectory (HLT) learning design 
is able to develop better conceptual understanding. Learning is increasingly meaningful for students using HLT. In addition, by using HLT, the series of activities designed to develop students' thinking skills in constructing material. (Ramadhanti, 2015)

The results of this research are also supported by previous research related to apply the Hypothetical Learning Trajectory (HLT) conducted by Wijaya which shows that learning with the Hypothetical Learning Trajectory can encourage prospective teachers to be able to present effective learning for students who experience learning problems in the class and can develop student learning skills (Wijaya, 2015) to have an impact on students' results. Elisabet Ayunika also revealed that, in learning the trajectory hypothesis, learning that has been compiled, corresponds to the learning process in the classroom and supports students in expanding their understanding of concepts (Ayunika et al., 2011). In this research, the Hypothetical Learning Trajectory (HLT) method with the zakat theory was used to improve student learning outcomes in the comparison material, in obtaining the results that there was the positive influence on applying the Hypothetical Learning Trajectory (HLT) using the Nisab Zakat theory to student learning outcomes.

\section{CONCLUSION AND SUGGESTION}

From the results of the research found that in working on the activity sheet, the students are very challenged in doing it. They are very interested in working on the problem of comparison using the Nisab Zakat theory, and the HLT used is the latest innovation in the learning. From the results of statistical calculations obtained data that learning by combining religious theory with mathematical theory, especially the comparison material using the theory of Nisab zakat has a positive effect on the student learning outcomes.

Based on the conclusions of the research results , the researcher gives several suggestions that students should be expected to always update new things in accordance with mathematical material. The lecturer should combine the learning of mathematics in the material of comparison with the Nisab Zakat theory, and hopefully there will be further research on mathematical theory that is combined with the religion theory.

\section{REFERENCE}

Agustina, I. W., \& Amin, S. M. (2013). Profil Pengajuan Soal Matematika Siswa Kelas VII SMP Pada Materi Perbandingan Ditinjau Dari Perbedaan Kemampuan Matematika Dan Perbedaan Jenis Kelamin. MATHEdunesa, 2(2), 1-8.

Argarini, D. F., Budiyono, \& Sujadi, I. (2014). Karakteristik Berpikir Kreatif Siswa Kelas VII SMP N 1 Kragan Dalam Memecahkan Dan Mengajukan Masalah Matematika Materi Perbandingan Ditinjau Dari Gaya Kognitif. JMME, IV(2), 1-12.

Asmawati, R., \& Wuryanto. (2014). Keefektifan Model Pembelajaran LC 5E Dan TSTS Berbantuan LKPD Terhadap Hasil Belajar. Jurnal Kreano, 5(1), 26-32.

Asnaini. (2015). Optimalisasi Zakat Dalam Ekonomi Islam (Studi Terhadap Sumber Zakat Dan Pengembangannya Di Indonesia). Jurnal Al-'Adl, 8(2), 1-17. 
Ayunika, E., Sari, P., Studi, P., Matematika, P., Sanata, U., \& Yogyakarta, D. (2011). Pengembangan Hipotesis Trayektori Pembelajaran Untuk Konsep Pecahan. In Matematika dan Pendidikan Karakter dalam Pembelajaran (pp. 206-212).

Charitas, R., Prahmana, I., \& Kusumah, Y. S. (2016). The Hypothetical Learning Trajectory on Research in Mathematics Education Using Research-Based Learning. Pedagogika, 123(3), 42-54.

Elizondo, B. R., \& Hernández-solís, A. (2016). Hypothetical Learning Trajectories that use digital technology to tackle an optimization problem. Technology and Its Integration in Mathematics Education, 29(2), 2-5.

Febrian, F. Hartoyo, A. Suratman, D. (2016). Pendekatan Matematika Realistik Terhadap Penalaran Matematis Pada Materi Perbandingan SMP. Jurnal Pendidikan dan Pembelajaran, 5(7) 1-10

Fitriana, D., Yusuf, M., \& Susanti, E. (2016). Pengembangan Lembar Kerja Siswa Menggunakan Pendekatan Saintifik Untuk Melihat Berpikir Kritis Siswa Materi Perbandingan. Jurnal Pendidikan Matematika, 10(2), 1-17.

Fuadiah, N. F. (2017). Hypothetical Learning T Rajectory Pada Pembelajaran Bilangan Negatif Berdasarkan Teori Situasi Didaktis Di Sekolah Menengah. Jurnal Mosharafa, 6(1), 1324.

Gravemeijer,K.,\& Eerde, D.V. (2009). Design Research as a Means for Building a Knowledge Base for Teaching in Mathematics Education. The Elementari School Journal, 109(5), 510-524.

Gravemeijer, K. (2004). Local Instructional Theories as Means of Support for Teachers in Reform Mathematics Education. Mathematical Thinking and Learning, 6(2), 105-128.

Hadi, N. (2016). Pengetahuan Masyarakat terhadap Nisab Zakat Tanaman Padi di Desa Pasar Inuman ditinjau Menurut Hukum ISLAM (Doctoral dissertation, Universitas Islam Negeri Sultan Syarif Kasim Riau).

Hasanah, U. (2016). Penerapan Strategi Pembelajaran Mind Mapping Untuk Meningkatkan Hasil Belajar Peserta Didik Pada Mata Pelajaran Fiqih Kelas VII A MTS Nurul Islam Air Bakoman Kabupaten Tanggamus. Al-Idarah : Jurnal Kependidikan Islam, 6(2), 4160 .

Hidayatulloh, H. (2017). Relasi Ilmu Pengetahuan dan Agama. Proceedings of the ICECRS, 1(1).

Ilma, R., \& Putri, I. (2012). Pendisainan Hypotetical Learning Trajectory ( Hlt ) Cerita Malin Kundang Pada Pembelajaran. In Kontribusi Pendidikan Matematika dan Matematika dalam Membangun Karakter Guru dan Siswa (pp. 978-979).

Jamhur, D. M. (2014). Rekontruksi Fiqh Zakat Perhiasan Dalam Perspektif Qadhi Abu Syuja' Al-Asfahani dan A. Hassan. Asy-Syari'ah, 16(2), 136-144. 
Johar, R. (2016). The Development Of Hypothetical Learning Trajectory ( Hlt ) For Teaching Circle With Realistic Mathematics Approach. In The Fourth South East Asia Design/Development Research International Conference 2016 (pp. 226-235).

Kristin, F., \& Rahayu, D. (2016). Pengaruh Penerapan Model Pembelajaran Discovery Learning Terhadap Hasil Belajar IPS Pada Siswa Kelas 4 SD. Scholaria, 6(1), 84-92.

Kusmaryono, H. (2015). Efektifitas pembelajaran diskoveri-inkuiri berbantuan cd interaktif terhadap hasil belajar materi kurs tukar valuta asing dan neraca pembayaran di SMA Negeri 1 Bae Kudus. Jurnal Pendidikan Ekonomi Dinamika Pendidikan, 10(1), 16-27.

Maulidiyahwarti, G., Sumarmi, \& Amirudin, A. (2016). Pengaruh Model Problem Based Learning Berbasis Outdoor Study Terhadap Hasil Belajar Siswa Kelas XI IIS SMA. Jurnal Pendidikan: Teori, Penelitian, Dan Pengembangan, 1(2), 94-100.

Megawati, I., Siahaan, S. M., \& Andriani, N. (2014). Penggunaan Strategi Pembelajaran Konflik Kognitif Dilengkapi Hypotethycal Learning Trajectory Pada Pokok Bahasan Suhu Dan Kalor di SMA Negeri 1 Tanjung Raja. Jurnal Inovasi Dan Pembelajaran Fisika, 1(2), 127-136.

Mendrofa. K.N. (2017). Pengembangan Alur Pembelajaran Perbandingan Berbasis Realistic Mathematics Education untuk Siswa Kelas VII SMP. Jurnal Lemma. III(2):1-17

Misrianti, B. F., Sugiatno, \& Hamdani. (2014). Wawancara Klinis Berbantuan Alat Peraga Untuk Mengatasi Kesulitan Siswa Dalam Materi Perbandingan Trigonometri Di Sma. Jurnal Pendidikan Dan Pembelajaran Untan, 3(4), 1-11.

Munif, A. (2012). Analisis Pendapat Khalifah Umar Bin Khattab tentang Penundaan Penarikan Zakat Binatang Ternak Kambing yang Telah Mencapai Nisab. Jurnal Mustaqid, 3(2), 205-230.

Nurdin. (2011). Trajektori dalam Pembelajaran Matematika. Edumatica, 1(April), 1-7.

Nuruddin, M. (2014). Transformasi Hadis-Hadis Zakat Dalam Mewujudkan Ketangguhan Ekonomi Pada Era Modern. Jurnal Zakat Dan Wakaf, 1(2), 294-314.

Pertiwi, K. R. (2017). Pembelajaran pecahan dengan menggunakan manik susun. Jurnal Review Pembelajaran Matematika, 2(2), 153-166.

Prahmana,R.C.I.(2017). Design Research. Depok: Rajawali Pers.

Pratiwi, K. K., \& Santosa, N. B. (2013). Pengaruh Pembelajaran Team Assisted Individualization (TAI) Berbantuan Media Smart And Interesting Card (SIC) Terhadap Hasil Belajar Siswa. Jurnal Inovasi Pendidikan Kimia, 7(2), 1210-1219.

Putra, Y.Y.,Zulkardi.,\& Hartono, Y. (2016). Pengembangan Soal Matematika Model PISA Menggunakan Konteks Lampung. Jurnal Kreano, 7(1): 10-16. 
Putri, R.I.I.(2012). Pendisainan Hypotetical Learning Trajectory (HLT) Cerita Malin Kundang Pada Pembelajaran Matematika. Prosiding Seminar Nasional Jurusan Pendidikan Matematika, 10 November 2012, FMIPA UNY

Rahayu, P., Retno, D., \& Saputro, S. (2015). Eksperimentasi Model Problem Based Learning Dan Discovery Learning Pada Materi Perbandingan dan Skala Ditinjau dari Sikap Peserta Terhadap Matematika Didik Kelas VII SMP Kabupaten Klaten Tahun Pelajaran 2013 / 2014. Jurnal Elektronik Pembelajaran Matematika, 3(3), 242-256.

Ramadhanti, P. (2015). Penggunaan Hypothetical Learning Trajectory (Hlt) Pada Materi Elastisitas Untuk Mengetahui Lintasan Belajar Siswa Kelas X Di Sma Negeri 1 Indralaya Utara. Jurnal Inovasi Dan Pembelajaran Fisika, 2(1), 88-99.

Rhamandica, C., Wonorahardjo, S., \& Arief, M. (2016). Pengaruh Pembelajaran Berbasis WEB Terhadap Hasil Belajar Mahasiswa Jurusan Kimia Pada Materi Kimia Inti Dengan Kemampuan Self Regulated Learning Berbeda. Jurnal Pendidikan : Teori, Penelitian, Dan Pengembangan, 1(10), 1891-1896.

Ridwan, M. (2014). Zakat Vs Pajak : Studi Perbandingan di Bebarapa Negara Muslim. Jurnal Zakat Dan Wakaf, 1(1), 124-144.

Risnanosanti. (2012). Hypothetical Learning Trajectory Untuk Menumbuhkembangkan Kemampuan Berpikir Kreatif. In Matematika dan Pendidikan Karakter dalam Pembelajaran (pp. 978-979).

Rudiono, T., Dafik, \& Wahyuningrum, E. (2015). Pengembangan Perangkat Pembelajaran Berbasis Rme Berorientasi Terciptanya Berfikir Tingkat Tinggi Materi Perbandingan Kelas VII. Pancaran, 4(1), 45-54.

Safaredha, D. E.(2014). Design Research Pembelajaran Perbandingan Pada Aktivitas Pengukuran. JPM IAIN Antasari, 1(2): 61-72

Salafudin. (2015). Pembelajaran Matematika yang Bermuatan Nilai Islam. Jurnal Penelitian, 12 (2): 223-243.

Septiono, D., \& Darminto, B. P. (2014). Perbandingan Pembelajaran Matematika Dengan Hypnoteaching Dan Ekspositori Terhadap Hasil Belajar Pada Materi Limit Fungsi. Ekuivalen, 12(2), 214-219.

Sholohin, M.I.N., Paris, M.A.,(2017). Kemampuan Siswa Memecahkan Masalah pada Materi Perbandingan dengan Menggunakan Model Pembelajaran Problem Based Instruction di Kelas VII MTs Noorhidayah Darussalam. Jurnal Ilmiah Kependidikan, 6(1): 1 - 8.

Simon, Martin A. (1995). Reconstructing Mathematics Pedagogy from a Conswtructive Perspective. Journal of Research in Mathematics Education, 26(2): 135-137.

Sugiyono. (2016). Statistika untuk Penelitian. Bandung: Alfabeta. 
Sumarto, S. N., Van Galen, F., Zulkardi, Z., \& Darmawijoyo, D. (2013). Proportional Reasoning: How do the 4th Graders Use Their Intuitive Understanding?. International Education Studies, 7(1), 69.

Susilo, Y., \& Khabibah, S. (2013). Peningkatan Motivasi Belajar Siswa Melalui Model Pembelajaran Kooperatif Tipe Numbered Head Together ( Nht ) Materi Ajar Perbandingan Dan Fungsi Trigonometri Pada Siswa Kelas X. MATHEdunesa, 2(2), 18.

Trianingsih, L., \& Hidayah, R. (2014). Studi Perbandingan Efektivitas Material Bambu Dan Batu Bata Sebagai Konstruksi Dinding. Inersia, X(1), 44-52.

Utari, R. S. (2017). Desain Pembelajaran Materi Perbandingan Menggunakan Konteks Resep Empek-Empek Untuk Medukung Kemampuan Bernalar Siswa SMP. Jurnal Pendidikan Matematika RAFA, 3(1), 103-121.

Utari, R. S., Putri, R.I., \& Hartono, Y. (2015). Konteks Kebudayaan Palembang untuk Mendukung Kemampuan Bernalar Siswa SMP pada Materi Perbandingan: Jurnal Didaktik Matematika 2(2), 27-37.

Wibowo, H., Rif'at, \& Hamdani. (2015). Remediasi materi perbandingan menggunakan strategi solusi berbantuan tabel pada siswa kelas vii smp. Jurnal Pendidikan Dan Pembelajaran Untan, 4(1), 1-11.

Wijaya, A. F. C. (2015). Profil Kemampuan Analisis Respon Siswa melalui Hypothetical Learning Trajectory ( HLT ) sebagai Instrumen Pembelajaran dalam Pengembangan Beragam Kemampuan Siswa. In Prosiding Simposium Nasional Inovasi dan Pembelajaran Sains 2015 (SNIPS 2015) 8: 185-188.

Yusefri. (2017). Penggunaan Hadis Māl Al-Mustafād dan Qiyās Sebagai Dalil Penetapan Hukum, Haul, dan Nisab Zakat Profesi. Al-Quds : Jurnal Studi Al-Quran Dan Hadis, 1(2), 148-168. 